\title{
Comparative study of growth curves in poultry
}

\author{
H Knížetová, J Hyánek, L Hyánková, P Bělíček \\ Research Institute of Animal Production, 10400 Prague 10-Uhřiněves, Czech Republic
}

(Received 26 April 1993; accepted 6 February 1995)

\begin{abstract}
Summary - This paper compares the growth patterns of chickens, turkeys, ducks and geese. The growth curves and their parameters were estimated by the Richards function. In this work, weight data of females of current sire lines (62 chickens, 47 ducks and 42 geese) and commercial medium-type hybrids (27 turkeys) were used. Birds were fed ad libitum and weighed at 7 or $14 \mathrm{~d}$ intervals up to $18-28$ weeks of age. The accuracy of the curve fit was high in all species $\left(R^{2}=0.9840\right.$ to 0.9994$)$. The ratios $y^{+} / A$ (weight at the inflection point over mature weight), which determine the shape of the growth curve, were 0.370 , $0.358,0.407$ and 0.261 in chickens, turkeys, ducks and geese, respectively. Only the growth pattern of the Galliforms did not significantly differ from the Gompertz type of growth $\left(y^{+} / A=0.368\right)$. The age at the inflection point confirmed the high early growth of geese $\left(t^{+}=21.1 \mathrm{~d}\right)$ and ducks $\left(t^{+}=25.5 \mathrm{~d}\right)$. The chickens finished the autoacceleration phase of growth at $47.7 \mathrm{~d}$ and turkeys at $74.0 \mathrm{~d}$ of age. The phenotypic correlations between the inflection parameters $t^{+}$and $y^{+}$were higher in waterfowl than in chickens and turkeys. The inflection parameter $t^{+}$and $y^{+}$were positively associated with the maturing index $k$ in ducks and geese, and negatively in chickens and turkeys. The evolutionary aspects of the interspecific differences are discussed.
\end{abstract}

growth curve / turkey / waterfowl / chicken / evolution

Résumé - Étude comparative des courbes de croissance de volaille. L'article compare les patrons de croissance du poulet, de la dinde, du canard et de l'oie. Les courbes de croissance et leurs paramètres ont été estimés selon l'équation de Richards. L'analyse a porté sur les poids de femelles de lignées paternelles courantes (62 poulets, 47 canards et 42 oies) et de 27 dindes (hybrides commerciaux de type moyen). Les oiseaux ont été nourris ad libitum et pesés régulièrement jusqu'à l'âge de 18 à $28 \mathrm{sem}$. La précision de l'ajustement des courbes est élevée pour les 4 espèces $\left(\mathrm{R}^{2}=0,9840\right.$ à 0,9994 ). Le rapport $\mathrm{y}^{+} / A$ (poids au point d'inflexion sur poids adulte) qui définit la forme de la courbe de croissance est de 0,370, 0,358, 0,407 et 0,261 pour le poulet, la dinde, le canard et l'oie respectivement. Seul le patron de croissance des Galliformes ne diffère pas significativement de la fonction de Gompertz $\left(\mathrm{y}^{+} / A=0,368\right)$. L'âge au point d'inflexion confirme la précocité de croissance de l'oie $\left(\mathrm{t}^{+}=21,1 j\right)$ et du canard $\left(\mathrm{t}^{+}=25,5 j\right)$. La période d'auto-accélération de la croissance dure $47,7 j$ chez le poulet et $74 j$ chez la dinde. Les corrélations phénotypiques entre les paramètres d'inflexion $\mathrm{t}^{+}$et $\mathrm{y}^{+}$sont plus élevées chez le canard et l'oie que chez 
le poulet et la dinde. Les liaisons entre les paramètres d'inflexion $\mathrm{t}^{+}$et $\mathrm{y}^{+}$et l'index de maturation $\mathrm{k}$ sont positives chez le canard et l'oie et négatives chez le poulet et la dinde. Les aspects évolutifs des différences interspécifiques sont discutés dans l'article.

courbe de croissance / dinde / palmipède / poule / évolution

\section{INTRODUCTION}

Variation in growth curves of different species of domestic birds is predominantly related to the evolutionary differences between the wild ancestors of these species.

The shape of the growth curve results from the growth rate and its changes during ontogenesis. Some comparisons of growth, fat deposition and efficiency of meat production in domestic birds, ie chickens and turkeys (Galliforms), ducks and geese (Anseriforms), have been presented by Nixey (1986) and Shalev and Pasternak (1989). Further comparative analyses of the growth patterns in poultry were carried out by Salomon et al $(1988,1990)$ and Anthony et al (1991).

The purpose of this study was to compare the parameters of growth curves in chickens, turkeys, ducks and geese obtained using the Richards function, and to give some interpretation to these differences which arose between species during evolution and, more recently, through artificial selection.

\section{MATERIALS AND METHODS}

Comparisons involved 4 independent data sets of female birds. The chicken, duck and goose data were previously described by Knížetová et al (1991a,b, 1994). While most of the analyzed species of meat-type domestic birds, the chicken (Gallus gallus domesticus), the duck (Anas platyrhynchos) and the goose (Anser anser), were represented by females of the sire line, only medium-size commercial hybrid females were used for the turkey (Meleagris gallopavo) data sets. The chicken line was developed from White Cornish and White Plymouth Rock, the synthetic strain of geese was descended from the Bohemian and Italian White geese, and Pekin ducks were of Czech origin.

The weight data from 178 birds (62 chickens, 27 turkeys, 47 ducks and 42 geese) were used for the analysis. All birds were reared on litter floor pens with an additional outdoor watering area for ducks and geese. Both food and water were available ad libitum. The starter diet for the chickens during the first 3 weeks contained $209 \mathrm{~g}$ protein and $11.7 \mathrm{MJ} \mathrm{ME} / \mathrm{kg}$, and the grower diet, fed up to 26 weeks, contained $189 \mathrm{~g}$ protein and $11.3 \mathrm{MJ} \mathrm{ME} / \mathrm{kg}$. The diet for the turkeys during the first 4 weeks contained $280 \mathrm{~g}$ protein and $11.3 \mathrm{MJ} \mathrm{ME} / \mathrm{kg}$; grower diet 1 contained $234 \mathrm{~g}$ protein and 11.6 MJ ME $/ \mathrm{kg}$ (up to 8 weeks of age) and grower diet 2 contained $180 \mathrm{~g}$ protein and $11.6 \mathrm{MJ} \mathrm{ME} / \mathrm{kg}$ (up to 12 weeks of age). During the final phase of growth, the turkeys were fed on a diet with $158 \mathrm{~g}$ protein and $12.0 \mathrm{MJ}$ $\mathrm{ME} / \mathrm{kg}$. The ducks were fed on a starter diet containing $176 \mathrm{~g}$ protein and 11.4 MJ $\mathrm{ME} / \mathrm{kg}$ from hatching to 3 weeks of age, followed by a grower diet with $148 \mathrm{~g}$ protein and $11.4 \mathrm{MJ} \mathrm{ME} / \mathrm{kg}$ to 10 weeks of age and a diet for mature ducks with $133 \mathrm{~g}$ 
protein and 11.4 MJ ME/kg during the final growth phase. The composition of these diets for the geese was $241 \mathrm{~g}$ protein and $11.3 \mathrm{MJ} \mathrm{ME} / \mathrm{kg}, 179 \mathrm{~g}$ protein and 11.3 MJ ME/kg and $102 \mathrm{~g}$ protein and 11.1 MJ ME/kg, respectively.

Birds were weighed at 7 or $14 \mathrm{~d}$ intervals up to $18-28$ weeks of age according to species and growth period, with the exception of the geese, which were weighed at longer intervals during the final growth period. The individual growth curves of chickens, turkeys, ducks and geese were based on 14, 19, 15 and 13 weight-age data.

The body weight $y_{t}$ of each individual during postnatal growth was described by the 4-parameter Richards function (Richards, 1959):

$$
y_{t}=A\left(1 \pm b e^{-k t}\right)^{-(1 / n)}
$$

for $n>-1, n \neq 0, \mathrm{~A}$ and $k>0$.

The biological interpretation of the parameters, estimated using generalised least squares methods, is as follows:

$A=$ asymptotic value of size as $t \rightarrow \infty$, generally interpreted as average size at maturity,

$b=$ integration constant, time scale parameter,

$k=$ ratio of the relative intensity of growth of transformed variable $\theta\left(=y^{n}\right)$ and degree of maturity expressed as $1-\left(\theta / A^{n}\right)$; this ratio estimates the maturation rate of the curve ( $i e$ the relative rate at which $A$ is reached),

$n=$ shape parameter determining the position of the inflection point of the curve (in the original Richards function it was designated as $m(m=n+1)$ and by other authors as $M(M=-1 / n))$; it established the degree of maturity in body weight at the point of inflection.

Weight $\left(y^{+}\right)$and age $\left(t^{+}\right)$at the inflection point were calculated from the parameters of the curve:

$$
y^{+}=\frac{A}{(n+1)^{1 / n}} \quad t^{+}=-\frac{1}{k} \ln \left|\frac{n}{b}\right|
$$

Further parameters included the average absolute growth rate $v(\mathrm{~g} / \mathrm{d})$ and maximal growth rate $v^{+}(\mathrm{g} / \mathrm{d}$ at inflection point):

$$
v=\frac{A k}{2(n+2)} \quad v^{+}=\frac{k}{n+1}
$$

The degree of maturity was also characterised by $u_{t}$ (Taylor and Fitzhugh, 1971):

$$
u_{t}=\frac{y_{t}}{A}
$$

The coefficient of determination $\left(R^{2}\right)$ characterised the fit of the curve to the observed pattern of growth. The null hypothesis $\left(n \rightarrow 0, y^{+} / A=0.368\right.$, the value corresponding to the Gompertz function) and the differences between species were tested by the $t$-test. 


\section{RESULTS}

The observed and theoretical live weights of female chickens, turkeys, ducks and geese are presented in table I, and their growth curves in figure 1 . The interspecific differences in the degree of maturity in terms of live weight are illustrated in figure 2.

The increase in weight of ducks and geese was very rapid early in life, and then it declined quickly in ducks. The growth of geese continued at later ages. On the other hand, turkeys and chickens increased in weight more slowly during the first few weeks, but they sustained weight gain for a longer period. The waterfowl were noticeably heavier than the gallids during the first 10 weeks of life. Conspicuous interspecific differences were also obtained for the ratio of mature weight to hatching weight. This ratio was 59, 70, 114 and 163 in geese, ducks, chickens and turkeys, respectively.

The high coefficients of determination $\left(R^{2}=0.9840-0.9994\right)$ indicate the Richards function was well suited to all 4 species (table I). In chickens, the theoretical weights were underestimated between the ages of 22 and 26 weeks, and overestimated in the middle of the growth period (16-18 weeks). In turkeys, the differences between predicted and observed weights tended to alternate in sign at short intervals.

The parameters of the Richards function are shown in table II. The shape of the growth curve determined by the inflection point position in terms of weight (ie ratio $y^{+} / A$ ) in chickens, turkeys, ducks and geese was $0.370,0.358,0.407$ and 0.261 , respectively. This ratio was not significantly different from the value $(0.368)$ expected under the Gompertz type of growth in chickens and turkeys. Although the growth rate during the first weeks of postnatal life is similar in ducks and geese, both species are conspicuously different in the shape of the growth curve. The growth pattern of ducks is characterised by a high sigmoid curving. On the other hand, the point of inflection for the geese was at the beginning of growth. This growth pattern seems to be determined by the rapid onset of growth during the first week after hatching (table I), as well as by a relatively long duration of linear growth (fig 1) followed by a slow decrease.

The position of the inflection point in terms of age confirmed the earliness of growth in geese $\left(t^{+}=21.1 \mathrm{~d}\right)$ and ducks $\left(t^{+}=25.5 \mathrm{~d}\right)$. The chickens finished the autoacceleration phase of growth at $47.7 \mathrm{~d}$ and turkeys at $74.0 \mathrm{~d}$ of age.

The $k$ parameter is largely determined by the value of the shape parameter $n$ $\left(r_{\mathrm{p}}\right.$ between $n$ and $k$ was $0.88-0.92$ ). Since $k$ depends on $d y / d t$ (the instantaneous absolute growth rate), $A, y^{+}$and $t^{+}$, it expresses the amount of growth rate as well as the rate of its change. The lowest value of $k$ was found in turkeys and the highest value in ducks. The similar value of $k$ for chickens and geese was associated with different maturing rates (fig 2). In geese, the low value of $k$ was determined by the position of the inflection point at the beginning of the linear growth phase.

The parameter $A$ (the asymptotic weight) approximated mature weight very closely in the waterfowl. In chickens, $A$ was lower than the observed live weight at the age of 26 weeks. The asymptotic weight of turkeys seemed to be overestimated (tables I and II). The body weight at the inflection point $\left(y^{+}\right)$was substantially lower in the waterfowl than in the gallids. On the other hand, the growth curve parameters, the definition of which includes both absolute values of body weight 


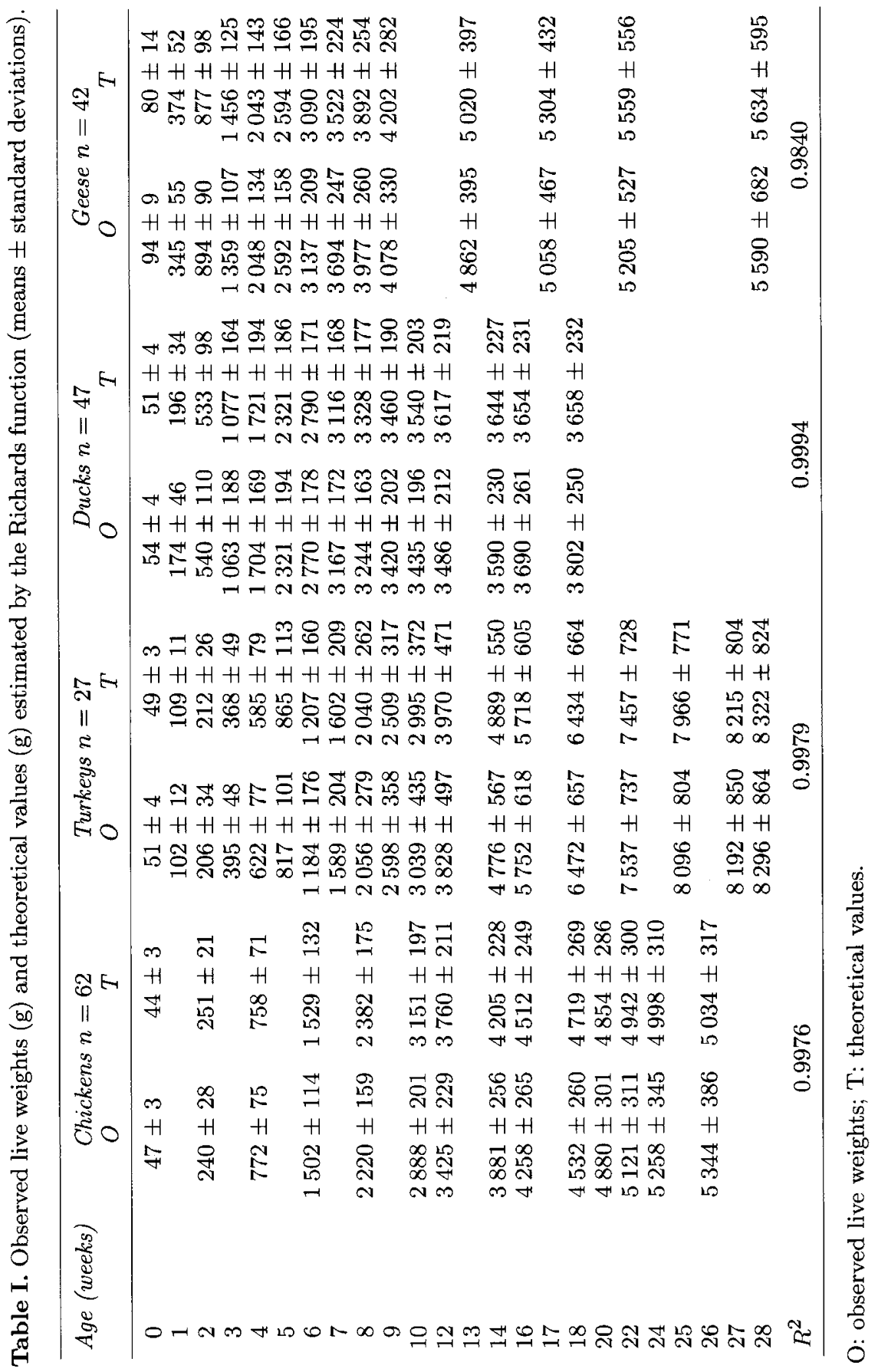




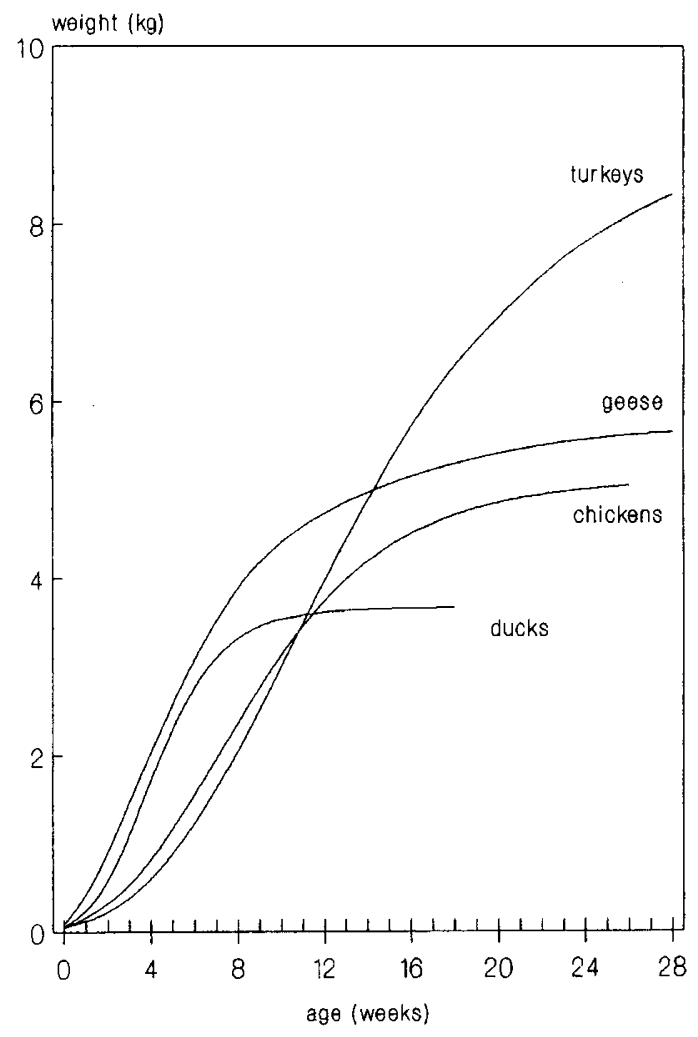

Fig 1. Growth curves.

and the earliness of growth, as for $v$ and $v^{+}$, had higher values in ducks and geese than in chickens and turkeys.

The interspecific differences may also be documented by differential relationships between parameters of the Richards function (table III). In the waterfowl, the correlation coefficients between $k$ and the inflection parameters $\left(y^{+}\right.$and $\left.t^{+}\right)$were positive, while in the gallids they were negative. The differences were statistically significant. Likewise, the relationship between $A$ and $y^{+}$was significantly stronger in species with a longer autoacceleration growth phase (chickens, turkeys), while the correlation coefficients between the parameters of the inflection point, ie $t^{+}$and $y^{+}$, were generally higher in ducks and geese.

\section{DISCUSSION}

\section{Growth pattern}

The growth patterns of chickens, turkeys, ducks and geese follow the sigmoid curve described by Brody (1945). However, there are large species-specific differences. 
a)

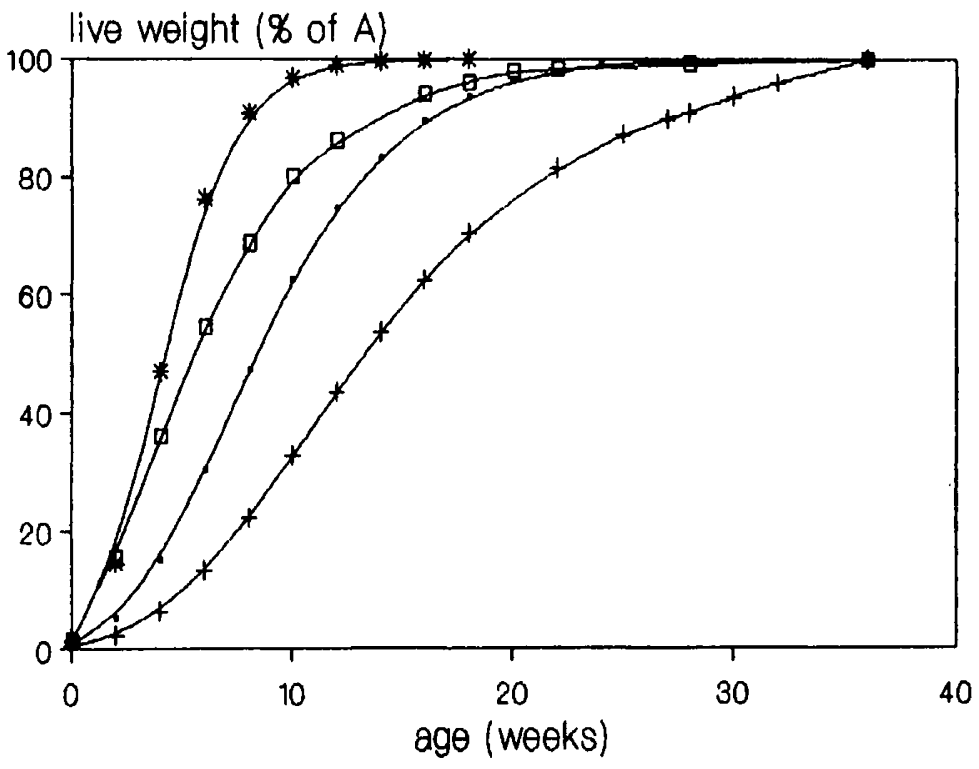

b)

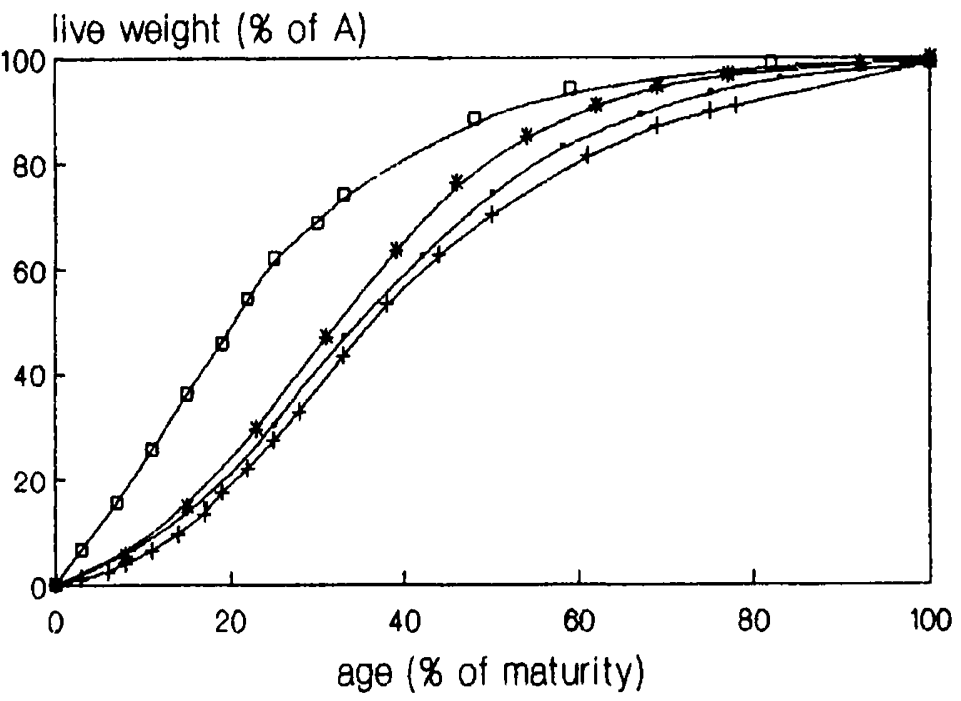

Fig 2. Relative growth curves. $\bullet$ chickens; + turkeys; $*$ ducks; $\square$ geese; age of maturity $=$ $100 \%(14,26,26$ and 36 weeks for ducks, geese, chickens and turkeys, respectively). 
Table II. Parameters of Richards function (means \pm standard errors).

\begin{tabular}{lcccc}
\hline & Chickens & Turkeys & Ducks & Geese \\
\hline$A(\mathrm{~g})$ & $5053 \pm 37.6^{\mathrm{c}}$ & $9150 \pm 244.7^{\mathrm{d}}$ & $3660 \pm 34.0^{\mathrm{a}}$ & $5677 \pm 96.3^{\mathrm{b}}$ \\
$b$ & $0.05 \pm 0.001^{\mathrm{c}}$ & $-0.17 \pm 0.061^{\mathrm{b}}$ & $2.51 \pm 0.497^{\mathrm{d}}$ & $-0.84 \pm 0.031^{\mathrm{a}}$ \\
$k(\ln \theta / \mathrm{d})$ & $0.033 \pm 0.0002^{\mathrm{b}}$ & $0.021 \pm 0.0007^{\mathrm{a}}$ & $0.079 \pm 0.0016^{\mathrm{c}}$ & $0.032 \pm 0.0011^{\mathrm{b}}$ \\
$n$ & $0.01 \pm 0.000^{\mathrm{c}}$ & $-0.05 \pm 0.017^{\mathrm{b}}$ & $0.24 \pm 0.008^{\mathrm{d}}$ & $-0.45 \pm 0.022^{\mathrm{a}}$ \\
$y^{+}(\mathrm{g})$ & $1869 \pm 13.9^{\mathrm{b}}$ & $3251 \pm 66.2^{\mathrm{c}}$ & $1486 \pm 14.4^{\mathrm{a}}$ & $1474 \pm 35.7^{\mathrm{a}}$ \\
$t^{+}(\mathrm{d})$ & $47.7 \pm 0.33^{\mathrm{c}}$ & $74.0 \pm 1.17^{\mathrm{d}}$ & $25.5 \pm 0.38^{\mathrm{b}}$ & $21.1 \pm 0.54^{\mathrm{a}}$ \\
$y^{+} / A$ & $0.370 \pm 0.0001^{\mathrm{b}}$ & $0.358 \pm 0.0036^{\mathrm{b}}$ & $0.407 \pm 0.0032^{\mathrm{c}}$ & $0.261 \pm 0.0062^{\mathrm{a}}$ \\
$v(\mathrm{~g} / \mathrm{d})$ & $41.8 \pm 0.29^{\mathrm{a}}$ & $48.0 \pm 1.08^{\mathrm{b}}$ & $64.2 \pm 0.63^{\mathrm{d}}$ & $57.4 \pm 0.81^{\mathrm{c}}$ \\
$v^{+}(\mathrm{g} /$ day $)$ & $61.4 \pm 0.43^{\mathrm{a}}$ & $70.6 \pm 1.58^{\mathrm{b}}$ & $94.8 \pm 0.94^{\mathrm{d}}$ & $85.6 \pm 1.12^{\mathrm{c}}$ \\
\hline
\end{tabular}

Means with different superscripts within rows are significantly different $(P<0.01)$ according to the $t$-test.

Table III. Phenotypic correlations between growth parameters within species.

\begin{tabular}{lcccc}
\hline Correlated parameters & Chickens & Turkeys & Ducks & Geese \\
\hline$k$ and $n$ & a & $0.92^{* * *}$ & $0.88^{* * *}$ & $0.89^{* * *}$ \\
$k$ and $A$ & $-0.48^{* * *}$ & $-0.68^{* * *}$ & $-0.55^{* * *}$ & $-0.59^{* * *}$ \\
$k$ and $y^{+}$ & $-0.48^{* * *}$ & $-0.35^{*}$ & $0.18^{\mathrm{NS}}$ & $0.43^{* *}$ \\
$k$ and $t^{+}$ & $-0.98^{* * *}$ & $-0.70^{* * *}$ & $0.20^{\mathrm{NS}}$ & $0.41^{* *}$ \\
$k$ and $v$ & $0.42^{* *}$ & $0.52^{* *}$ & $0.60^{* * *}$ & $0.71^{* * *}$ \\
$A$ and $y^{+}$ & $1.00^{* * *}$ & $0.91^{* * *}$ & $0.66^{* * *}$ & $0.37^{*}$ \\
$t^{+}$and $y^{+}$ & $0.57^{* * *}$ & $0.44^{* *}$ & $0.66^{* * *}$ & $0.92^{* * *}$ \\
\hline
\end{tabular}

a The shape parameters were the same in all birds, accordingly the correlations could not be calculated. ${ }^{*} P<0.05$; $^{* *} P<0.01 ;{ }^{* * *} P<0.001$; NS $=$ not significant.

Our results on the comparative analysis of growth curves of these species confirmed the earliness of growth in Anseriforms (geese, ducks) and the late maturing in Galliforms (chickens, turkeys) (Nixey, 1986; Salomon et al, 1988; Shalev and Pasternak, 1989). This conclusion is also compatible with findings of Björnhag (1979) who reported that geese had the highest growth rate factor (1.73), which may be taken as a measure of growth rate when the difference of birth weight between species is eliminated. This implies that geese grow about 1.7 times faster than most other birds. The corresponding values for ducks, chickens and turkeys were 0.89 , 0.57 and 0.47 , respectively. According to the author, there is reason to believe that growth capacity for ducks is higher than the calculated growth rate factor. In a comparative study of chickens, ducks and turkeys, Shalev and Pasternak (1989) found that ducks had the highest and turkeys the lowest initial specific growth rate and rate of exponential decay of this growth rate (the Gompertz function). By using the Janoschek functions. Salomon et al $(1988,1990)$ found analogous results with $0.352,0.394,0.414$ and $0.303\left(y^{+} / A\right)$ and $52.3,74.4,27.6$ and $24.3 \mathrm{~d}\left(t^{+}\right)$for chickens, turkeys, ducks and geese, respectively. 
The most extreme interspecific differences in the shape of the growth curves have been found between geese and ducks. The geese are characterised by the lowest ratio of the inflection and asymptotic weights $(0.261)$. This value is nearest to that for the Bertalanffy function (0.296), although higher values (0.333) have been obtained for commercial hybrids (unpublished data). In contrast, the values of $y^{+} / A$ in the different lines of Pekin ducks ranged from 0.386 to 0.424 (Knížetová et al, 1991b).

Generally, a higher genetic heterogeneity in both gallinaceous species is due to the long-term intensive selection for different objectives during domestication. Examining 4 breeds (White Cornish, New Hampshire, White Leghorn and Orpington), 3 highly inbred lines of White Leghorn, and 9 broiler lines, we found the ratio $y^{+} / A$ to range in value from 0.332 to 0.392 (Knížetová et al, 1983, 1985, 1991a). In turkeys, 3 size categories (small, medium and heavy) have been selected, which will probably affect the shape of the growth curve. The medium type of turkeys was used in both studies, but overestimating $A$ in our work (caused probably by the high weight gain between 27 th and 28 th weeks of age) accounts for a lower value of $y^{+} / A$ than that of Salomon. Nevertheless, the overall similarity between the growth patterns of chickens and turkeys found in this work could be expected as their wild ancestors had a similar mode of life.

\section{Evolution}

The birds living in areas where food supply changes dramatically with the seasons, therefore causing them to migrate at an early age, may be expected to have a higher growth rate than those living in areas with a more permanent food supply (Björnhag, 1979). Indeed, geese represent a northern migrating genus adapted to shorter summers, whereas the gallids are mostly resident species. On the other hand, the fast growth of ducks immediately after hatching might be associated with semiaquatic habitats of their wild ancestors. Wild ducks seek food on water. Consequently, natural selection might confer some advantage to birds with rapid fat accumulation. Since the body fat in the waterfowl is also an insulating tissue to preserve body heat.

Differences in the growth pattern were also found between the altricial and precocious species. Early parental dependence in altricial birds is generally accompanied by rapid growth to fledging, a pattern converse to that observed in precocial species (Ricklefs, 1968, 1973). Tyller (unpublished results) found that pigeons (altricial) and ducks (precocious) had a similar shape for their growth curve, even though their mode of life was different. The pigeons attain the inflection and mature weight at 8 and $24 \mathrm{~d}$ of age, respectively, with a ratio of these 2 weights, $y^{+} / A$, around 0.450 , a result compatible with weight-age data of Aggrey and Cheng (1993).

\section{Animal improvement}

From a practical point of view, the difference between ages at slaughter and at the inflection point is important. Ducks and geese are slaughtered relatively late in the autoretardation phase of growth, when the growth rate has decreased substantially. At a slaughter age of 7 weeks, ducks reach $85 \%$ of their mature weight, but the ratio is only $35 \%$ for chickens. Geese and turkeys are usually killed around 16 weeks of age, when they have attained approximately 95 and $65 \%$ of their mature weight. 
The corresponding value for broiler geese (at a slaughter age of about 9 weeks) is $74 \%$. Moreover, the waterfowl have a higher body weight and a more intensive metabolism than chickens and, consequently, their maintenance requirements are higher (Leeson et al, 1982). They also have more fat deposition. Therefore, waterfowl have a higher food consumption per kilogram of live weight at slaughter, compared with chickens. Slaughter of turkeys generally takes place after the inflection point of the growth curve as well, but not as late as for waterfowl.

The differences between breeds and lines in the shape of the growth curve suggest that selection for body weight may alter the growth pattern (Ricard, 1975; Marks, 1978; Tzeng and Becker, 1981; Parks, 1982; Zelenka et al, 1986). Age at selection may contribute to the timing and magnitude of the growth response observed. Selection for high live weight prior to $t^{+}$(chickens) appeared to result in a younger age and lower relative body weight at $t^{+}$. Selection after $t^{+}$(quail and turkeys) had the same effect on the age at the inflection point, but increased the relative weight at $t^{+}$(Anthony et al, 1991). According to these authors, most differences in the shape of the growth curve among quail, chickens and turkeys occurred between hatching and the point of inflection. The growth of all 3 species after $t^{+}$was generally found to be comparable. Recently, Barbato (1992) reported that selection for high growth rate immediately after hatching $(0-14 \mathrm{~d}$ of age) did not change the body weight at maturity, while selection for high body weight, at or near the age of the inflection point of the growth curve resulted in increased adult body weight.

\section{REFERENCES}

Aggrey SE, Cheng KM (1993) Genetic and posthatch parental influences on growth in pigeon squabs. $J$ Hered $84,184-187$

Anthony NB, Emmerson DA, Nestor KE, Bacon WL, Siegel PB, Dunnington EA (1991) Comparison of growth curves of weight selected populations of turkey, quail, and chickens. Poult Sci 70, 13-19

Barbato GF (1992) Divergent selection for exponential rate at 14 or 42 days of age. 1. Early responses. Poult Sci 72, 687-697

Björnhag G (1979) Growth in newly hatched birds. Swed J Agric Res 9, 121-125

Brody S (1945) Bioenergetics and Growth. Reinhold Publ Corp, New York, USA

Knížetová H, Kníže B, Hyánek J et al (1983) Growth curves of highly inbred lines of fowl and their $\mathrm{F}_{1}$ hybrids. Genet Sel Evol 15, 533-558

Knížetová H, Hyánek J, Hájková H, Kníže B, Šiler R (1985) Growth curves of chickens with different type of performance. $Z$ Tierz Züchtungsbiol 102, 256-270

Knížetová H, Hyánek J, Kníže B, Roubíček J (1991a) Analysis of growth curves of fowl. I. Chickens. Br Poult Sci 32, 1027-1038

Knížetová H, Hyánek J, Kníže B, Procházková H (1991b) Analysis of growth curves of fowl. II. Ducks. Br Poult Sci 32, 1039-1053

Knížetová H, Hyánek J, Veselský A (1994) Analysis of growth curves of fowl. III. Geese. Br Poult Sci 35, 415-423

Leeson S, Summers JD, Proulx J (1982) Production and carcass characteristics of the duck. Poult Sci 61, 2456-2464

Marks HL (1978) Growth curve changes associated with long-term selection for body weight in Japanese quail. Growth 42, 129-140 
Nixey C (1986) A comparison of growth and fat deposition of commercial avian species. 7th European Poultry Conference, Paris, August 24-28, World Poultry Science Association, 671-680

Parks JR (1982) The growth parameters and the genetics of growth and feeding. In: $A$ Theory of Feeding and Growth of Animals (JR Parks, ed), Springer-Verlag, Berlin, Germany 230-242

Ricard FH (1975) Essai de sélection sur la forme de la courbe de croissance chez le poulet. Ann Génét Sélect Anim 7, 427-443

Richards FJ (1959) A flexible growth function for empirical use. J Exp Bot 10, 290-300

Ricklefs RE (1968) Patterns of growth in birds. Ibis 110, 419-451

Ricklefs RE (1973) Patterns of growth in birds. II. Growth rate and mode of development. Ibis $115,177-200$

Salomon FV, Sager G, Al Hallak M, Pingel H (1988) Wachstumsspezifische Approximationen von 11 Körperdimensionen bei Geflügel. 5. Mitteilung: Vergleichende Betrachtung des Wachstums von Hühnern, Enten and Gänsen. Arch Geflügelk 52, 176-180

Salomon FV, Anger Th, Krug H, Gille U, Pingel H (1990) Zum Wachstum von Skelett, Körpermasse und Muskelfaserdurchmesser der Pute (Meleagris gallopavo) vom Schlupf bis zum 224. Lebenstag. Anat Histol Embryol 19, 314-325

Shalev A, Pasternak H (1989) Meat production efficiencies of turkey, chicken and duck broilers. World Poult Sci 45, 109-114

Taylor SCS, Fitzhugh HA (1971) Genetic relationships between mature weight and time taken to mature within a breed. J Anim Sci 33, 726-731

Tzeng RY, Becker WA (1981) Growth patterns of body and abdominal fat weight in male broiler chickens. Poult Sci 60, 1101-1106

Zelenka DJ, Dunnington EA, Siegel PB (1986) Growth to sexual maturity of dwarf and nondwarf White Rock chickens divergently selected for juvenile body weight. Theor Appl Genet 73, 61-65 